\title{
Methane mitigation and ruminal fermentation changes in cows fed cottonseed and
}

\section{vitamin $\mathrm{E}$}

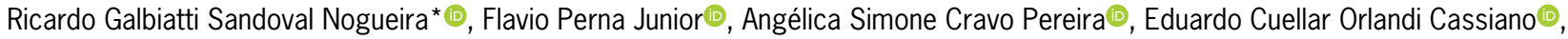 \\ Roberta Ferreira Carvalho ${ }^{\circledR}$, Paulo Henrique Mazza Rodrigues (i)
}

Universidade de São Paulo/FMVZ - Depto. de Nutrição e Produção Animal, Av. Duque de Caxias Norte, 225 - 13653900 - Pirassununga, SP - Brasil.

*Corresponding author <rick_galbiatti@hotmail.com>

Edited by: Antonio Faciola

Received September 25, 2018

Accepted May 03, 2019
ABSTRACT: Inherently, ruminant production of methane $\left(\mathrm{CH}_{4}\right)$, a greenhouse gas (GHG), causes animal energy losses. Cottonseed is a lipid source and is used sometimes to enhance energy density in cattle diets. It also can mitigate enteric $\mathrm{CH}_{4}$. Lipids release peroxides in the rumen, and antioxidants have the ability to neutralize them. Thus, a lipid and antioxidant source can benefit rumen fermentation. The aim of this study was to evaluate rumen fermentation parameters from cows fed cottonseed and vitamin E. Six cannulated cows were arranged in a replicate $3 \times 3$ latin square. Treatments were: 1) Control, 2) CS (30\% corn replaced by cottonseed) and 3) CSVitE (30 \% corn replaced by cottonseed, plus $500 \mathrm{IU}$ VitE). Results were compared by orthogonal contrast. When compared to the control diet, cottonseed inclusion reduced enteric $\mathrm{CH}_{4}$ emissions by $42 \%$. Production of acetate, butyrate and the acetate to propionate ratio were respectively $34 \%, 47 \%$ and $36 \%$ lower with the cottonseed treatments. Energy lost in the rumen as $\mathrm{CH}_{4}$ and energy release as butyrate were reduced by $26 \%$ and $32 \%$ respectively. Propionate and intestinal energy release were, respectively, $43 \%$ and $35 \%$ higher with cottonseed treatments. Furthermore, as a nutritional strategy to mitigate enteric $\mathrm{CH}_{4}$ cottonseed has positive effects on short chain fatty acid (SCFA) production and gastrointestinal energy release. Vitamin E did not result in improvements in ruminal fermentation. Further studies evaluating levels of vitamin $E$ in association with different amounts and sources of lipids are required.

Keywords: SCFA, enteric methane, oilseed, antioxidant

\section{Introduction}

Enteric methane emissions from ruminants are problematic with respect to the energy utilization efficiency of feed, and they also have an environmental impact. According to Buddle et al. (2011), $5 \%$ to $9 \%$ of gross energy consumed by animals is lost as $\mathrm{CH}_{4}$ This represents $14 \%$ of anthropogenic GHGs and $25 \%$ of the $\mathrm{CH}_{4}$ emissions from human activities (Gerber et al., 2013). Methane mitigation feeding strategies are therefore a priority for improving animal productivity and environmental sustainability (Beauchemin et al., 2011), although resources relative to this subject and the relationship between methane mitigation and animal performance could be more thoroughly reported in the relevant literature.

Incorporating oilseeds into cattle diets has been shown to reduce enteric $\mathrm{CH}_{4}$ emissions, as reported by Beauchemin et al. (2008) and Martin et al. (2010). Although the influence of lipids in methane emissions, digestibility and rumen fermentation vary between studies, this may be associated with the type and concentration of fatty acids in diet (Grainger and Beauchenin, 2011).

Ruminal microorganisms are predominantly anaerobes and have a less developed antioxidant capacity (Brioukhanov and Netrusov, 2004). Dietary lipids, if not biohydrogenated in terms of potential oxidation, can be significant contributors to the load of peroxides in the rumen. According to Andrews et al. (2006), it is possible that raising peroxide concentrations would be enough to create an oxidative stress condition in ruminal microor- ganisms that could compromise their activity for optimal growth.

A common way to attempt to reduce or prevent lipid peroxidation is through the use of antioxidants. In recent years, supplemental vitamin $\mathrm{E}$ in the diet of ruminants has been studied for its potential role in preventing lipid peroxidation (Bloomberg et al., 2011). The reasoning being that supplementing vitamin $\mathrm{E}$ to relieve oxidation effects could be beneficial to rumen microorganisms by improving fermentation production and changing the gastrointestinal availability of energy for the cows. Feeding an antioxidant, such as $\alpha$-tocopherol, alleviates the negative effect of a high level of unsaturated fat supplementation on microbial growth and SCFA utilization by the rumen microflora (Hino et al., 1993).

In this study, we began by hypothesizing that oilseed not only has beneficial effects on rumen fermentation, but also produces a number of undesirable effects in terms of peroxidation products, and that vitamin E could decrease the negative effects of fatty acids on ruminal fermentation. The overall aim of this research was therefore to investigate the effects of cottonseed and vitamin $\mathrm{E}$ inclusion on methane and SCFA production, as well as to evaluate the energy release in the gastrointestinal tract of cows.

\section{Materials and Methods}

\section{Study location and ethical care}

The study was conducted at Pirassununga, São Paulo, Brazil (Latitude: -21.996; Longitude: -47.4268 
$21^{\circ} 59^{\prime} 46^{\prime \prime} \mathrm{S}, 47^{\circ} 25^{\prime} 36^{\prime \prime} \mathrm{W}$; Altitude: 625 meters). The experiment was approved by and complied with the guidelines set out by the Ethics Committee by the Use of Animals of the University of São Paulo, under application number $n^{\circ} 009 / 2013$, in respect of animal experimentation and care of animals used for scientific purposes.

\section{Animals, housing and feeding}

Six Holstein dairy cows were sorted into individual pens that had free access to water and a sand bed. They were neither pregnant nor lactating; they had ruminal cannula, and the average of their body weights was $876 \mathrm{~kg}( \pm 16.1)$. Cows were fed ad libitum twice daily (08h00 and 16h00) with the same amount in each meal. The feed was weighed daily and offered to each animal after the feed residue from the previous day had been removed. The vitamin $\mathrm{E}$ amount offered was 500 IU per animal per day. To administer this, a powder containing $50 \%$ alpha tocopheryl acetate was top-dressed on the diet and immediately mixed with a pitchfork at the bunker. This inclusion rate for Vitamin $\mathrm{E}$ was determined according to Scrist et al., (1998), who stated that the addition of Vitamin $\mathrm{E}$ at a rate of $500 \mathrm{mg} \mathrm{kg}^{-1}$ of DM improves both feed efficiency and economic justifications.

\section{Experimental design and treatments}

A replicated $3 \times 3$ Latin squared design with 3 periods was used. Three dietary treatments were defined: 1) C - Control diet, 2) CS - Control diet with $30 \%$ cottonseed replacing ground corn grain, and 3) CSVitE - the CS diet supplemented with vitamin $\mathrm{E}$. The dietary levels for fatty acids and cottonseed levels were determined according to Andrae et al. (2001). Diets had a forage-concentration rate of $16: 84$, in which sugar bagasse was the main fiber source. Soybean meal and urea were the primary protein sources; for energy content, ground corn grain was replaced by cottonseed. Nutritional demands were estimated by the NRC system (2001) with the aim of daily mean weight gain of $1.2 \mathrm{~kg} \mathrm{~d}^{-1}$. The ingredients and chemical compositions of the experimental diets are presented in Table 1.

\section{Feed intake}

Feed intake was measured from the $11^{\text {th }}$ to the $15^{\text {th }}$ days of each period by weighing feeds offered to and refused by the cows. Refusal was recorded once daily and the feeding rate was adjusted to yield orts on the basis of at least $10 \%$ of the amount supplied (on an as-fed basis). Dry matter intake was determined by multiplying feed intake by respective dietary dry matter.

\section{Ruminal emptying}

The last 2 days of each period - before morning feeding and $3 \mathrm{~h}$ after morning feeding respectively - ruminal contents were manually removed according to Chilibroste et al. (2000). Using a strainer, ruminal con-
Table 1 - Ingredients and chemical composition of dietary treatments.

\begin{tabular}{|c|c|c|c|}
\hline & \multicolumn{3}{|c|}{ Dietary treatments } \\
\hline & Control & CS & CSVitE \\
\hline \multicolumn{4}{|l|}{ Ingredient } \\
\hline Sugarcane bagasse, $\mathrm{g} \mathrm{kg}^{-1}$ of DM & 134 & 134 & 134 \\
\hline Cottonseed, $\mathrm{g} \mathrm{kg}^{-1}$ of DM & - & 304 & 304 \\
\hline Ground corn grain, $\mathrm{g} \mathrm{kg}^{-1}$ of DM & 572 & 281 & 281 \\
\hline Citrus pulp, $\mathrm{g} \mathrm{kg}^{-1}$ of DM & 183 & 183 & 183 \\
\hline Soybean meal, $\mathrm{g} \mathrm{kg}^{-1}$ of DM & 81.7 & 81.7 & 81.7 \\
\hline Minerals, $\mathrm{g} \mathrm{kg}^{-1}$ of DM & 60.0 & 60.0 & 60.0 \\
\hline Limestone, $\mathrm{g} \mathrm{kg}^{-1}$ of DM & 40.0 & 40.0 & 40.0 \\
\hline Urea, $\mathrm{g} \mathrm{kg}^{-1}$ of DM & 13.7 & 2.70 & 2.70 \\
\hline Vitamin $\mathrm{E}, \mathrm{mg} \mathrm{kg}^{-1}$ of DM & - & - & 500 \\
\hline \multicolumn{4}{|l|}{ Chemical composition } \\
\hline $\mathrm{DM}, \mathrm{g} \mathrm{kg}^{-1}$ & 891 & 910 & 910 \\
\hline $\mathrm{CP}, \mathrm{g} \mathrm{kg}^{-1}$ of DM & 158 & 160 & 160 \\
\hline $\mathrm{RDP}^{1}, \mathrm{~g} \mathrm{~kg}^{-1}$ of $\mathrm{CP}$ & 302 & 366 & 366 \\
\hline $\mathrm{RUP}^{2}, \mathrm{~g} \mathrm{~kg}^{-1}$ of $\mathrm{CP}$ & 69.8 & 63.4 & 63.4 \\
\hline$E E, g ~ k g^{-1}$ of $D M$ & 26.1 & 76.9 & 76.9 \\
\hline $\mathrm{NDF}, \mathrm{g} \mathrm{kg}^{-1}$ of DM & 234 & 357 & 357 \\
\hline ADF, $\mathrm{g} \mathrm{kg}^{-1}$ of $\mathrm{DM}$ & 171 & 265 & 265 \\
\hline Lignin, $\mathrm{g} \mathrm{kg}^{-1}$ of DM & 55.3 & 136 & 136 \\
\hline $\mathrm{Ca}, \mathrm{g} \mathrm{kg}^{-1}$ of $\mathrm{DM}$ & 15.7 & 18.2 & 18.2 \\
\hline $\mathrm{P}, \mathrm{g} \mathrm{kg}^{-1}$ of $\mathrm{DM}$ & 12.7 & 14.7 & 14.7 \\
\hline Hemicellulose $^{3}, \mathrm{~g} \mathrm{~kg}^{-1}$ of DM & 63.0 & 92.0 & 92.0 \\
\hline Cellulose $^{4}, \mathrm{~g} \mathrm{~kg}^{-1}$ of DM & 115 & 136 & 136 \\
\hline $\mathrm{OM}^{5}, \mathrm{~g} \mathrm{~kg}^{-1}$ of DM & 829 & 845 & 845 \\
\hline $\mathrm{NFC}^{6}, \mathrm{~g} \mathrm{~kg}^{-1}$ of DM & 525 & 328 & 328 \\
\hline Gross energy, $\mathrm{MJ} \mathrm{kg}^{-1}$ of DM & 17.3 & 17.8 & 17.8 \\
\hline${ }^{7}$ Vitamin $\mathrm{E}, \mathrm{mg} \mathrm{kg}^{-1}$ of DM & 14.0 & 7.00 & 507 \\
\hline
\end{tabular}

$\mathrm{DM}=$ dry matter; $\mathrm{OM}=$ organic matter; $\mathrm{CP}=$ crude protein; $\mathrm{EE}=$ ether extract; $\mathrm{NDF}=$ neutral detergent fiber; $\mathrm{ADF}=$ acid detergent fiber; $\mathrm{Ca}=$ calcium; $\mathrm{P}$ $=$ phosphorus; $\mathrm{NFC}=$ Non-fibrous carbohydrate; ${ }^{1} \mathrm{RDP}=$ rumen degradable protein estimated according to NRC (2001); ${ }^{2}$ RUP = rumen undegradable protein estimated according to NRC (2001); ${ }^{3}$ Hemicellulose $=$ NDF - ADF; ${ }^{4}$ Cellulose $=$ ADF - Lignin; ${ }^{5} \mathrm{OM}=\mathrm{DM}-$ mineral; ${ }^{6} \mathrm{NFC}=100-(\mathrm{CP}+\mathrm{NDF}+\mathrm{EE}$ + ash); ' Vitamin E: estimated according to NRC (2001).

tents were separated into solid and liquid phases, and were then weighed and sampled. Immediately thereafter, ruminal contents were returned into the rumen. The solid and liquid samples were dried at $60{ }^{\circ} \mathrm{C}$ (forced-air oven) for $72 \mathrm{~h}$ in order to determine the dry matter content of each sample. Ruminal solid mass was calculated by the sum of solid and liquid content adjusted by its respective dry matter content.

\section{Nutrient digestibility and fecal output}

Dry matter digestibility and fecal output were determined using chromium oxide as an external marker as according to Bateman (1970). From the $8^{\text {th }}$ until the $17^{\text {th }}, 15$ grams per head per day of indigestible marker was placed twice daily (08h00 and $16 \mathrm{~h} 00$ before feeding) via rumen fistula accordingly. Feces were manually collected twice a day from the rectum from the $13^{\text {th }}$ until the $17^{\text {th }}$ at $08 \mathrm{~h} 00$ and $16 \mathrm{~h} 00$ after feeding. A composite of $200 \mathrm{~g}$ samples was then analyzed for chromium oxide concentration according to Conceição et al. (2007). 


\section{Determination of Methane and SCFA production} $\mathrm{SCFA}, \mathrm{CH}_{4}$ and $\mathrm{N}-\mathrm{NH}_{3}$ productions were determined by the ex situ ruminal fermentation technique (Rodrigues et al., 2012; Perna Junior et al., 2017). The principle of this technique consists of leaving the ruminal content samples in bottles (as a micro-rumen), which are then incubated in a water bath at $39^{\circ} \mathrm{C}$. This simulates the prevailing conditions of the rumen (presence of microorganisms, anaerobic environment, a temperature of $39^{\circ} \mathrm{C}$, natural saliva, and physiological rumen $\mathrm{pH}$ ).

Ruminal content samples were collected on the 18th day of each period through the ruminal cannula at $0,3,6,9$ and $12 \mathrm{~h}$ after the morning meal. On this day, animals were fed once in the morning. The evening meal was offered only after the collection of the $12 \mathrm{~h}$ sample. Approximately $300 \mathrm{~mL}$ of rumen fluid (using a motorized vacuum pump) and $300 \mathrm{~g}$ of solid content (with hands) were collected at each sampling time from three different parts of the rumen (dorsal sac in the front, middle and back). The two fractions were mixed in the proportion of $66 \%$ liquid phase and $33 \%$ solid phase and homogenized before preparation for analysis of SCFA, $\mathrm{CH}_{4}$ and $\mathrm{N}-\mathrm{NH} 3$ using the ex situ ruminal fermentation technique (Perna Junior et al., 2017).

For each sample, four bottles were prepared; two were used for incubation $\left(\mathrm{T}_{30}\right)$ and two were used as blanks $\left(\mathrm{T}_{0}\right)$. The mixed rumen contents $(30 \mathrm{~mL})$ were pressed through a funnel into a $50 \mathrm{~mL}$ capacity bottle, which was then capped with rubber corks and sealed with an aluminum seal. The bottles were then flushed with $\mathrm{CO}_{2}$ through needles for input and output to ensure an anaerobic environment. After $30 \mathrm{~min}$ of incubation, fermentations were stopped by autoclaving at $121{ }^{\circ} \mathrm{C}$ $\left(250^{\circ} \mathrm{F}\right.$ ) and $100 \mathrm{kPa}$ (15 psi) above atmospheric pressure for $15 \mathrm{~min}$. The measurements of total gas volume produced in incubated $\left(\mathrm{T}_{30}\right)$ and not incubated $\left(\mathrm{T}_{0}\right)$ bottles were taken using a pressure transducer connected to a syringe with a needle. The gas volume was obtained from the sum of the volume obtained at the transducer plus the head space. $\mathrm{CH}_{4}$ concentration was determined by gas chromatography, injecting $0.5 \mathrm{~mL}$ of gas from each bottle, according to Kaminski et al. (2003) in a controlled temperature environment $\left(25^{\circ} \mathrm{C}\right)$.

The volume of liquid in the incubated $\left(\mathrm{T}_{30}\right)$ and not incubated $\left(\mathrm{T}_{0}\right)$ bottles was calculated as the difference between the weight of the bottle sample after drying in an oven with forced air circulation at $105{ }^{\circ} \mathrm{C}$ for $24 \mathrm{~h}$ and the weight of the bottles before heating in the oven. The solid content of the bottles was obtained by measuring the weight difference between the bottle containing the sample after drying in the oven and the weight of the empty bottle (before filling with ruminal content sample). For SCFA analyses (of acetate, propionate and butyrate), a fraction of ruminal fluid from each bottle was centrifuged at $2,000 \times \mathrm{g}$ for $20 \mathrm{~min}$, and $2.0 \mathrm{~mL}$ of the supernatant was added to $0.4 \mathrm{~mL}$ of formic acid and frozen at minus $20{ }^{\circ} \mathrm{C}$ for further analyses, according to Erwin et al. (1961). SCFA were measured by gas chromatography using a glass column, $1.22 \mathrm{~m}$ in length and $0.63 \mathrm{~cm}$ in diameter, packed with 80/120 Carbopack B-DA/4 \%.

The quantification of $\mathrm{CH}_{4}$ production was obtained by multiplying the total volume of gas $(\mathrm{mL})$ by the $\mathrm{CH}_{4}$ concentration in the gas phase, the $\mathrm{mmol} \mathrm{mL}^{-1}$ obtained in the incubated bottle $\left(\mathrm{T}_{30}\right)$. This result was subtracted from the value that was produced in the bottle not incubated $\left(\mathrm{T}_{0}\right)$. The individual quantification of SCFA was obtained by multiplying the liquid volume $(\mathrm{mL})$ by the concentration of each SCFA $\left(\mathrm{mmol} \mathrm{mL}^{-1}\right)$ obtained in the incubated bottle $\left(\mathrm{T}_{30}\right)$, and this value was also subtracted from that obtained from the bottle not incubated $\left(\mathrm{T}_{0}\right)$. $\mathrm{CH}_{4}$ and SCFA production was identified according to Perna Junior et al., 2017.

To determine energy from the fermentative products $\left(\mathrm{CH}_{4}\right.$ and SCFA), each product was multiplied by their respective combustion heat, so the relative energy loss (REL) was the ratio between the energy in the methane produced and the energy sum in all the quantified fermentation products $\left(\mathrm{CH}_{4}\right.$ and SCFA), expressed as a percentage. In making this examination, values and data from the literature were used that assumes: acetic, propionic, butyric, $\mathrm{CH}_{4}$ and $\mathrm{CO}_{2}$ had $3.49,4.98,5.96,13.16$ and 0.0 kcals per gram, or conversely, 209.40, 368.52, $524.48,210.56$ and 0.0 kcals per mol, respectively. The relative energy loss was calculated according to Perna Junior et al., 2017.

\section{Determination of nitrogen-ammonia concentration and balance}

For $\mathrm{N}-\mathrm{NH}_{3}$ concentration determination, a $2.0 \mathrm{~mL}$ centrifuged sample of each bottle (after microbial inactivation) was mixed with $1 \mathrm{~mL}$ of $1 \mathrm{~N}$ of $\mathrm{H}_{2} \mathrm{SO}_{4}$ solution. The tubes were then immediately frozen until the colorimetric analyses were carried out, according to the method described by Kulasek (1972). The balance was obtained by subtracting the $\mathrm{N}-\mathrm{NH}_{3}$ concentration after 30 min of incubation $\left(\mathrm{T}_{30}\right)$ from the baseline $\left(\mathrm{T}_{0}\right)$. With this procedure it is possible to evaluate whether on balance of ammonia production in the rumen is positive or negative. In this paper, this information was expressed in terms of changes in concentration $\left(\mathrm{mg} \mathrm{dL}^{-1}\right)$ per hour.

Notably in this study, the ex situ methodology was capable of evaluating $\mathrm{N}-\mathrm{NH}_{3}$ concentrations from the rumen for microorganisms, and through its incubation process, it is possible to determine the $\mathrm{N}-\mathrm{NH}_{3}$ balance.

\section{Gastrointestinal energy released}

Gross energy intake $\left(\mathrm{MJ} \mathrm{d}^{-1}\right)$ was calculated by multiplication of DMI $(\mathrm{kg})$ and diet gross energy $\left(\mathrm{MJ} \mathrm{kg}^{-1}\right)$. To calculate the energy release when expressed as $\mathrm{MJ} \mathrm{d}^{-1}$, the acetate, butyrate, propionate and methane productions $\left(\mathrm{g} \mathrm{kg}^{-1} \mathrm{~d}^{-1}\right)$ were multiplied by their respective combustion heat $\left(\mathrm{MJ} \mathrm{g}^{-1}\right)$, and then multiplied by their ruminal solid mass $(\mathrm{kg})$. The energy release in the rumen, when expressed in terms of \% gross energy intake (GEI) or \% digestive energy (DE), was obtained by dividing ac- 
etate, propionate, butyrate and methane releases $\left(\mathrm{MJ} \mathrm{d}^{-1}\right)$ by gross energy intakes $\left(\mathrm{MJ} \mathrm{d}^{-1}\right)$ or digestive energy (MJ $\mathrm{d}^{-1}$ ) and then multiplying the result by 100 .

Methane release in the cecum and colon (C\&C) was considered to be $5 \%$ of total methane release. Enteric methane is produced mainly in the rumen (95\%) and, to a smaller extent $(5 \%)$, in the large intestine (Dini et al., 2012).

Energy release in the intestine $\left(\mathrm{MJ} \mathrm{d}^{-1}\right)$ was calculated from the gross energy intake $\left(\mathrm{MJ} \mathrm{d}^{-1}\right)$ subtracted from the respective acetate, propionate, butyrate and methane releases in the rumen $\left(\mathrm{MJ} \mathrm{d}^{-1}\right)$, plus the feces' gross energy $\left(\mathrm{MJ} \mathrm{d}^{-1}\right)$ and methane releases in the cecum and colon $\left(\mathrm{MJ} \mathrm{d}^{-1}\right)$. The following equation 1 refers to:

$E R I=G E I-(\mathrm{C} 2+\mathrm{C} 3+\mathrm{C} 4+$ feces $\mathrm{GE}+\mathrm{C} \& \mathrm{C})$

where: $E R I=$ energy release in the intestine $\left(\mathrm{MJ} \mathrm{d}^{-1}\right)$, $G E I=$ gross energy intake $\left(\mathrm{MJ} \mathrm{d}^{-1}\right), \mathrm{C} 2=\operatorname{acetic}\left(\mathrm{MJ} \mathrm{d}^{-1}\right)$, $\mathrm{C} 3=$ propionic $\left(\mathrm{MJ} \mathrm{d}^{-1}\right), \mathrm{C} 4=$ butyric $\left(\mathrm{MJ} \mathrm{d}^{-1}\right)$, feces $\mathrm{GE}=$ energy release in the feces $\left(\mathrm{MJ} \mathrm{d}^{-1}\right)$, and $\mathrm{C} \& \mathrm{C}$ methane $=$ methane release in cecum and colon $\left(\mathrm{MJ} \mathrm{d}^{-1}\right)$.

The energy release in the intestine, expressed in terms of $\% \mathrm{GE}$ or \% $\mathrm{DE}$, was obtained by dividing energy release in the intestine $\left(\mathrm{MJ} \mathrm{d}^{-1}\right)$ by GEI $\left(\mathrm{MJ} \mathrm{d}^{-1}\right)$ or $\mathrm{DE}\left(\mathrm{MJ} \mathrm{d}^{-1}\right)$ and then, multiplying the result by 100 . Energy release in the feces, expressed in terms of \% GEI, was obtained by dividing feces' energy content $\left(\mathrm{MJ} \mathrm{d}^{-1}\right)$ by gross energy intake $\left(\mathrm{MJ} \mathrm{d}^{-1}\right)$ and then multiplying the result by 100 .

\section{Laboratory analysis}

Pooled feed ingredients, as well feces samples, were collected and stored at $-20{ }^{\circ} \mathrm{C}$. Samples were dried at $60^{\circ} \mathrm{C}$ for $48 \mathrm{~h}$ and milled through a $1 \mathrm{~mm}$ screen using a Wiley mill. The DM content was processed at $100{ }^{\circ} \mathrm{C}$ for $4 \mathrm{~h}$ followed by cold weighing (method 930.15, AOAC, 1995). Nitrogen content was determined by the micro Kjeldahl method (AOAC, 1995) using a nitrogen distiller, which was then multiplied by 6.25 to determine CP. EE was determined using light petroleum ether in the Soxhlet apparatus (method 920.39, AOAC, 1995). GE was determined by combustion using an adiabatic calorimeter bomb according to AOAC (1995). NDF, $\mathrm{ADF}$ and lignin were determined using the sequential method with heat stable $\alpha$-amylase (method 973.18, AOAC, 1995) using a fiber digester.

\section{Statistical analysis}

The data were analyzed using the MIXED procedure of SAS (Statistical Analysis System, version 9.0). Cows in each period were considered to be experimental units. Before the actual analysis, the data were first analyzed for the presence of disparate information ("outliers") and the normality of residuals (Shapiro-Wilk). An individual observation was considered outlier when standard deviations in relation to the mean were greater than +3 or less than -3 .
For the ruminal solid mass, gross energy intake, and energy release data, the model used included both the fixed effect of treatments and the random effects of square, period, and animals within the square. These variables were analyzed using the following model:

$$
Y_{i j k l}=\mu+T_{i}+P_{j}+S_{k}+A_{l}\left(S_{k}\right)+e_{i j k l}
$$

where: $Y_{i j k l}=$ the dependent response variable, $\mu=$ the overall mean, $T_{i}=$ the treatment effect, $P_{j}=$ the period effect, $S_{k}=$ the square effect, $A_{l}\left(S_{k}\right)=$ animals within square effect, and $e_{i j k l}=$ the residual error term.

For the methane SCFA and ammonia variables, data were analyzed using mixed models (PROC MIXED). From 15 different covariance structures tested, the selected model was chosen based on the lower value of the Corrected Akaike Information Criterion (AICC), (Wang and Goonewardene, 2004). In this model, the treatment, time and interaction treatment*time effects were considered fixed. The effects of period, square, and the animal within the square were considered random. These variables were analyzed using the following model:

$Y_{i j k l m}=\mu+T_{i}+P_{j}+S_{k}+A_{l}\left(S_{k}\right)+T_{I}+\left(T_{i} \times T I\right)_{i j}+e_{i j k l m}$

where: $Y_{i j k l m}=$ the dependent response variable, $\mu=$ the overall mean, $T_{i}=$ the treatment effect, $P_{j}=$ the period effect, $S_{k}=$ the square effect, $A_{l}\left(S_{k}\right)=$ cows within square effect, $T I=$ the time effect, $\left(T_{i} \times T I\right)_{i j}=$ the interaction treatment and time, and $e_{i j k l m}=$ the residual error term.

Contrast statements were used to evaluate differences between means, such as "C1" -Control vs. CS and CSVitE and "C2" - CS vs. CSVitE. Statistical significance was declared at $p \leq 0.05$.

\section{Results}

Due to the replacement of ground corn grain for cottonseed, the CS and CSVitE had higher values for rumen degradable protein (RDP), neutral digestive fiber (NDF), acid detergent fiber (ADF) and lignin, ether extract (EE), Hemicellulose and Cellulose. CS and CSVitE had lower values for rumen ungradable protein (RUP) and non-fibrous carbohydrate (NFC), when compared to the Control (Table 1).

\section{Ruminal parameters}

No effect was observed for the $\mathrm{N}-\mathrm{NH}_{3}$ concentration in the 0 and 30 min time frames. For the remaining hourly periods, animals fed vitamin $\mathrm{E}$ had a lower $\mathrm{N}-\mathrm{NH}_{3}$ balance $\left(0.85\right.$ vs. $\left.1.99 \mathrm{mg} \mathrm{dL}^{-1}\right)$ compared to those animals fed no vitamin $\mathrm{E}$ (Table 2).

The inclusion of cottonseed in the diet, with or without vitamin $\mathrm{E}$, decreased acetate $(p<0.0028)$, butyrate $(p<0.0001)$, and methane $(p<0.0001)$ production compared to the Control. Propionate production was similar among treatments. Furthermore, and 
Table 2 - Ruminal fermentation of non-lactating cows fed dietary treatments.

\begin{tabular}{|c|c|c|c|c|c|c|c|c|}
\hline & \multicolumn{3}{|c|}{ Treatments } & \multirow{2}{*}{ SEM } & \multicolumn{4}{|c|}{${ }^{*}$ Probability } \\
\hline & Control & CS & CSVitE & & $\mathrm{C} 1$ & $\mathrm{C} 2$ & Time & $\mathrm{T} \times \mathrm{Ti}$ \\
\hline \multicolumn{9}{|l|}{$\mathrm{N}-\mathrm{NH}_{3}, \mathrm{mg} \mathrm{dL}^{-1} \mathrm{~h}^{-1}$} \\
\hline $\mathrm{T}_{0}$ & 22.4 & 21.9 & 21.3 & 0.86 & 0.590 & 0.730 & 0.001 & 0.001 \\
\hline $\mathrm{T}_{30}$ & 23.5 & 23.9 & 22.2 & 0.93 & 0.756 & 0.349 & 0.001 & 0.001 \\
\hline Balance, hours & 1.11 & 1.99 & 0.85 & 0.41 & 0.149 & $<0.001$ & 0.150 & 0.508 \\
\hline \multicolumn{9}{|l|}{ Acetate } \\
\hline $\mathrm{T}_{0}, \mathrm{mmol} \mathrm{L}^{-1}$ & 71.1 & 67.2 & 67.1 & 0.89 & 0.123 & 0.967 & 0.011 & 0.152 \\
\hline $\mathrm{T}_{30}, \mathrm{mmol} \mathrm{L-1}$ & 76.1 & 71.3 & 71.0 & 0.99 & 0.020 & 0.913 & $<0.001$ & 0.181 \\
\hline $\mathrm{Mmol} \mathrm{g}^{-1}$ of DM h $\mathrm{h}^{-1}$ & 0.14 & 0.09 & 0.09 & 0.01 & 0.002 & 0.841 & 0.018 & 0.481 \\
\hline $\mathrm{mol} \mathrm{kg}^{-1}$ of DM d-1 & 3.50 & 2.39 & 2.23 & 0.19 & 0.002 & 0.725 & 0.018 & 0.246 \\
\hline $\mathrm{g} \mathrm{kg}^{-1}$ of $\mathrm{DM} \mathrm{d} \mathrm{d}^{-1}$ & 210 & 143 & 133 & 11.8 & 0.002 & 0.723 & 0.018 & 0.242 \\
\hline $\mathrm{EB}, \mathrm{MJ} \mathrm{kg}^{-1} \mathrm{~d}^{-1}$ & 3.06 & 2.10 & 1.95 & 0.04 & 0.010 & 0.709 & 0.018 & 0.538 \\
\hline \multicolumn{9}{|l|}{ Propionate } \\
\hline $\mathrm{T}_{0}, \mathrm{mmol} \mathrm{L}^{-1}$ & 15.2 & 20.7 & 20.9 & 0.49 & 0.001 & 0.124 & $<0.001$ & 0.020 \\
\hline $\mathrm{T}_{30}, \mathrm{mmol} \mathrm{L}^{-1}$ & 16.8 & 22.7 & 22.9 & 0.55 & 0.001 & 0.921 & $<0.001$ & 0.330 \\
\hline $\mathrm{Mmol} \mathrm{g}^{-1}$ of $\mathrm{DM} \mathrm{h} \mathrm{h}^{-1}$ & 0.04 & 0.04 & 0.04 & 0.01 & 0.122 & 0.993 & 0.010 & 0.179 \\
\hline $\mathrm{mol} \mathrm{kg}^{-1}$ of DM d-1 & 1.09 & 1.15 & 1.10 & 0.07 & 0.806 & 0.784 & 0.010 & 0.219 \\
\hline $\mathrm{g} \mathrm{kg}^{-1}$ of $\mathrm{DM} \mathrm{d}^{-1}$ & 80.9 & 85.3 & 82.0 & 5.51 & 0.801 & 0.791 & 0.010 & 0.221 \\
\hline $\mathrm{EB}, \mathrm{MJ} \mathrm{kg}^{-1} \mathrm{~d}^{-1}$ & 1.68 & 1.77 & 1.70 & 0.11 & 0.801 & 0.791 & 0.010 & 0.221 \\
\hline \multicolumn{9}{|l|}{ Butyrate } \\
\hline $\mathrm{T}_{0}, \mathrm{mmol} \mathrm{L}^{-1}$ & 12.7 & 9.34 & 9.12 & 0.29 & $<0.001$ & 0.712 & 0.059 & 0.075 \\
\hline $\mathrm{T}_{30}, \mathrm{mmol} \mathrm{L}^{-1}$ & 14.2 & 10.3 & 10.0 & 0.32 & $<0.001$ & 0.725 & 0.006 & 0.615 \\
\hline $\mathrm{Mmol} \mathrm{g}^{-1}$ of $\mathrm{DM} \mathrm{h} \mathrm{h}^{-1}$ & 0.04 & 0.02 & 0.02 & 0.00 & $<0.001$ & 0.504 & 0.019 & 0.121 \\
\hline $\mathrm{mol} \mathrm{kg}^{-1}$ of DM d-1 & 1.03 & 0.58 & 0.50 & 0.04 & $<0.001$ & 0.385 & 0.019 & 0.262 \\
\hline $\mathrm{g} \mathrm{kg}^{-1}$ of $\mathrm{DM} \mathrm{d} \mathrm{d}^{-1}$ & 90.7 & 51.3 & 44.3 & 4.22 & $<0.001$ & 0.388 & 0.019 & 0.255 \\
\hline $\mathrm{EB}, \mathrm{MJ} \mathrm{kg}^{-1} \mathrm{~d}^{-1}$ & 2.25 & 1.28 & 1.10 & 0.10 & $<0.001$ & 0.388 & 0.019 & 0.255 \\
\hline \multicolumn{9}{|l|}{ SCFA total } \\
\hline $\mathrm{T}_{0}, \mathrm{mmol} \mathrm{L}^{-1}$ & 99.0 & 97.3 & 97.1 & 13.3 & 0.624 & 0.971 & 0.004 & 0.093 \\
\hline $\mathrm{T}_{30}, \mathrm{mmol} \mathrm{L}^{-1}$ & 107 & 104 & 104 & 14.6 & 0.402 & 0.921 & 0.001 & 0.305 \\
\hline $\mathrm{Mmol} \mathrm{g}^{-1}$ of DM h $\mathrm{h}^{-1}$ & 0.23 & 0.17 & 0.16 & 0.01 & 0.005 & 0.805 & 0.046 & 0.448 \\
\hline $\mathrm{mol} \mathrm{kg}^{-1}$ of DM d-1 & 5.62 & 4.13 & 3.84 & 0.29 & 0.005 & 0.657 & 0.053 & 0.476 \\
\hline $\mathrm{g} \mathrm{kg}^{-1}$ of $\mathrm{DM} \mathrm{d}^{-1}$ & 381 & 280 & 260 & 19.6 & 0.005 & 0.692 & 0.049 & 0.434 \\
\hline $\mathrm{EB}, \mathrm{MJ} \mathrm{kg}^{-1} \mathrm{~d}^{-1}$ & 7.01 & 5.15 & 4.76 & 0.35 & 0.005 & 0.641 & 0.044 & 0.448 \\
\hline \multicolumn{9}{|l|}{ C2:C3 ratio } \\
\hline Concentration & 4.76 & 3.29 & 3.34 & 0.09 & $<0.001$ & 0.870 & $<0.001$ & 0.324 \\
\hline Production & 3.60 & 2.19 & 2.41 & 0.17 & 0.009 & 0.613 & 0.061 & 0.350 \\
\hline \multicolumn{9}{|l|}{ Methane } \\
\hline $\mathrm{T}_{0}, \mathrm{mmol} \mathrm{L}^{-1}$ & 0.03 & 0.02 & 0.02 & 0.00 & $<0.001$ & 0.430 & 0.627 & 0.837 \\
\hline $\mathrm{T}_{30}, \mathrm{mmol} \mathrm{L}^{-1}$ & 0.15 & 0.10 & 0.09 & 0.00 & $<0.001$ & 0.587 & $<0.001$ & 0.549 \\
\hline $\mathrm{Mmol} \mathrm{g}^{-1}$ of $\mathrm{DM} \mathrm{h}^{-1}$ & 0.11 & 0.06 & 0.06 & 0.00 & $<0.001$ & 0.323 & $<0.001$ & 0.783 \\
\hline $\mathrm{mol} \mathrm{kg}^{-1}$ of DM d-1 & 2.73 & 1.65 & 1.50 & 0.08 & $<0.001$ & 0.409 & $<0.001$ & 0.241 \\
\hline $\mathrm{g} \mathrm{kg}^{-1}$ of $\mathrm{DM} \mathrm{d}^{-1}$ & 43.7 & 26.4 & 24.1 & 1.42 & $<0.001$ & 0.356 & $<0.001$ & 0.356 \\
\hline $\mathrm{EB}, \mathrm{MJ} \mathrm{kg}^{-1} \mathrm{~d}^{-1}$ & 2.40 & 1.45 & 1.32 & 0.07 & $<0.001$ & 0.358 & $<0.001$ & 0.215 \\
\hline REL, \% & 31.3 & 29.6 & 27.3 & 1.36 & 0.462 & 0.598 & 0.567 & 0.364 \\
\hline
\end{tabular}

SCFA = short chain fatty acids; $\mathrm{C2}: \mathrm{C} 3$ ratio $=$ acetate to propionate ratio; $\mathrm{RE}=$ relative energy loss; $\mathrm{SEM}=$ standard error of the mean; $\mathrm{T} \times \mathrm{TI}=$ interaction treatment time ; NS $=p>0.10$; ${ }^{*}$ Probability: $\mathrm{C} 1=$ contrast 1 (CS and CSVitE vs. control); $\mathrm{C} 2=$ contrast 2 (CS vs. CSVitE).

in terms of total SCFA production $(p<0.0054)$, the acetate to propionate ratio $(p<0.0001)$ was reduced by cottonseed supplementation compared to the Control diet. Including cottonseed or vitamin $\mathrm{E}$ in diet did not affect the relative energy loss (REL) (Table 2). The interactions between times and treatments for the $\mathrm{N}-\mathrm{NH}_{3}(p<0.001)$ concentration were significant. In $\mathrm{T}_{0}$ and $\mathrm{T}_{30}$ specimens, cottonseed treatments had a higher
$\mathrm{N}-\mathrm{NH}_{3}$ concentration at $0 \mathrm{~h}$ post feeding and a lower concentration at $9 \mathrm{~h}$ post feeding vs. the Control (Figure 1). No interaction between time and treatment was observed for the acetate, butyrate or methane production; however, the result of the time effect was notable, $(p<0.05)$. The acetate, propionate, butyrate and methane productions were higher at $3 \mathrm{~h}$ post feeding and lower at $0 \mathrm{~h}$ post feeding (Figure 2). 


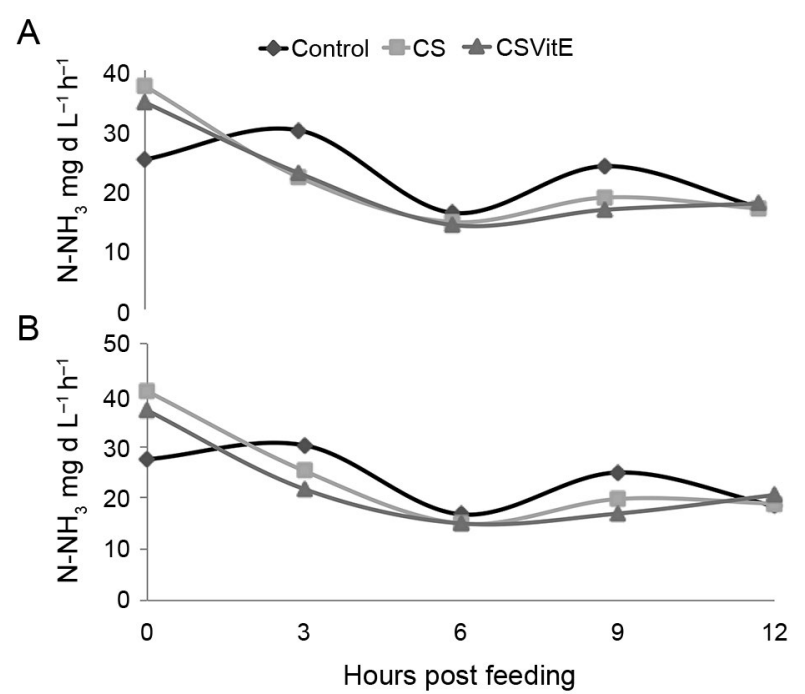

Figure 1 - Ruminal $\mathrm{N}-\mathrm{NH}_{3}$ concentration in the $\mathrm{T}_{0}(\mathrm{~A})$ and $\mathrm{T}_{30}(\mathrm{~B})$ over $12 \mathrm{~h}$ post feeding.

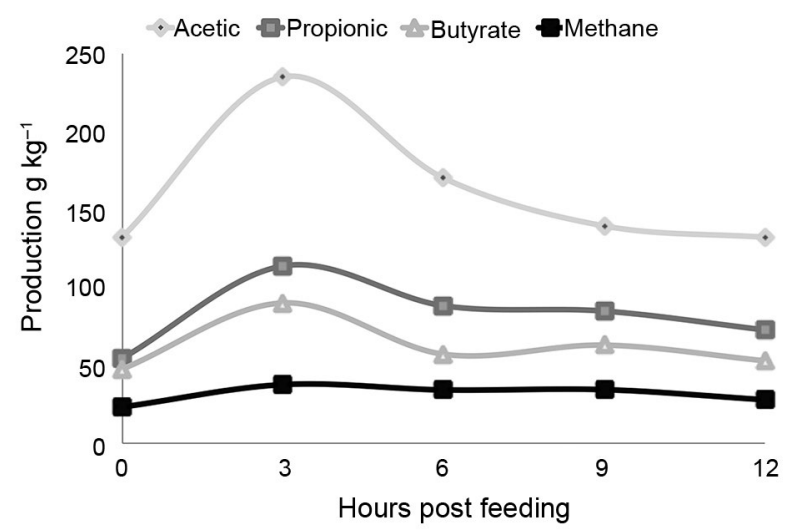

Figure 2 - Average production of acetate, propionate, butyrate and methane over $12 \mathrm{~h}$ post feeding.

\section{Gastrointestinal energy released}

No differences were observed in dry matter intake or dry matter excretion, gross energy intake, or digestive energy. The cottonseed inclusion diet, regardless of the VitE presence, resulted in $32 \%$ higher ruminal solid mass compared to the Control (Table 3).

Comparative results between other treatments vs. the Control were as follows: the propionate and intestine energy releases, when expressed as $\mathrm{MJ} \mathrm{d}^{-1}$, were respectively $43 \%(p<0.0343)$ and $57 \%(p<0.0405)$ higher for cows fed cottonseed. Butyrate and methane energy releases, when expressed as $\mathrm{MJ} \mathrm{d}^{-1}$, were, respectively, $32 \%(p<0.0033)$ and $26 \%(p<0.0013)$ lower for the cottonseed treatments. The acetate and feces energy releases, when expressed as $\mathrm{MJ} \mathrm{d}^{-1}$, were similar among treatments (Table 3).

Specifically, cottonseed treatments were lower vs. the Control in these results: The butyrate energy re-
Table 3 - Estimate of energy release in the gastrointestinal tract of cows fed different diets.

\begin{tabular}{|c|c|c|c|c|c|c|}
\hline & \multicolumn{3}{|c|}{ Treatments } & \multirow{2}{*}{ SEM } & \multicolumn{2}{|c|}{${ }^{*}$ Probability } \\
\hline & Control & CS & CSVitE & & C1 & $\mathrm{C} 2$ \\
\hline Ruminal solid mass, $\mathrm{kg}$ & 8.29 & 10.8 & 11.2 & 0.45 & $<0.001$ & 0.603 \\
\hline Dry matter intake, kg & 14.6 & 15.4 & 15.4 & 0.61 & 0.064 & 40.952 \\
\hline Dry matter excretion, $\mathrm{kg}$ & 3.67 & 4.02 & 4.06 & 0.19 & 0.437 & 70.912 \\
\hline Gross energy intake, $\mathrm{MJ} \mathrm{d}^{-1}$ & 211 & 245 & 245 & 13.0 & 0.107 & 70.979 \\
\hline Digestive energy, $\mathrm{MJ} \mathrm{d}^{-1}$ & 158 & 169 & 172 & 12.5 & 0.054 & 40.861 \\
\hline \multicolumn{7}{|l|}{ Energy release in the rumen } \\
\hline \multicolumn{7}{|l|}{ Acetate } \\
\hline$M J d^{-1}$ & 24.6 & 22.8 & 20.8 & 1.17 & 0.330 & 0.526 \\
\hline $\mathrm{GE}, \%$ & 11.9 & 9.88 & 9.39 & 0.96 & 0.295 & 0.824 \\
\hline $\mathrm{DE}, \%$ & 18.8 & 15.0 & 14.4 & 1.98 & 0.169 & 0.842 \\
\hline \multicolumn{7}{|l|}{ Propionate } \\
\hline$M J d^{-1}$ & 13.3 & 19.2 & 18.9 & 1.25 & 0.034 & 0.907 \\
\hline $\mathrm{GE}, \%$ & 6.40 & 8.05 & 8.09 & 0.55 & 0.465 & 0.977 \\
\hline $\mathrm{DE}, \%$ & 9.82 & 12.2 & 12.2 & 1.06 & 0.720 & 0.981 \\
\hline \multicolumn{7}{|l|}{ Butyrate } \\
\hline$M J d^{-1}$ & 19.2 & 13.9 & 12.2 & 1.00 & 0.003 & 0.304 \\
\hline GE, $\%$ & 9.22 & 5.78 & 5.07 & 0.51 & $<0.001$ & 0.292 \\
\hline $\mathrm{DE}, \%$ & 14.2 & 8.60 & 7.58 & 0.93 & 0.002 & 0.448 \\
\hline \multicolumn{7}{|l|}{ Methane } \\
\hline$M J d^{-1}$ & 20.5 & 15.7 & 14.5 & 1.12 & 0.001 & 0.441 \\
\hline $\mathrm{GE}, \%$ & 9.72 & 5.96 & 6.59 & 0.50 & $<0.001$ & 0.342 \\
\hline $\mathrm{DE}, \%$ & 15.0 & 9.87 & 8.73 & 0.93 & 0.003 & 0.003 \\
\hline \multicolumn{7}{|l|}{ Energy release in the intestine } \\
\hline$M J d^{-1}$ & 63.3 & 94.1 & 102 & 12.1 & 0.040 & 0.728 \\
\hline $\mathrm{GE}, \%$ & 27.3 & 36.1 & 38.9 & 3.61 & 0.023 & 0.625 \\
\hline $\mathrm{DE}, \%$ & 39.0 & 51.8 & 54.7 & 4.14 & 0.016 & 0.646 \\
\hline \multicolumn{7}{|l|}{ Energy release in the Feces } \\
\hline$M J d^{-1}$ & 66.9 & 75.7 & 72.8 & 4.30 & 0.176 & 0.702 \\
\hline GE, \% & 33.3 & 31.9 & 31.0 & 2.33 & 0.759 & 0.825 \\
\hline
\end{tabular}

leased expressed as \% GEI (5\% vs. $9 \%)(p<0.002)$ and $\%$ DE (8 \% vs. $14 \%)(p<0.0021)$. The methane energy released expressed as \% GEI $(6 \%$ vs. $9 \%)(p<0.005)$ and $\% \operatorname{DE}(9 \%$ vs $15 \%)(p<0.0031)$. The intestinal energy released expressed as \% GEI (37\% vs. $27 \%$ ) $(p<0.0239)$ and \% DE (53\% vs. $39 \%)(p<0.0231)$, the latter being the only result that was higher than the Control. The acetate and propionate \% GE and \% DE energy releases were similar among treatments (Table 3).

\section{Discussion}

\section{Ruminal parameters}

In the present study, the ruminal ammonia concentration $\left(\mathrm{T}_{0}\right)$ was, on average, $21.8 \mathrm{mg} \mathrm{dL}^{-1}$. According to Leng (1990), ruminal $\mathrm{N}-\mathrm{NH}_{3}$ should be greater than $10 \mathrm{mg} \mathrm{dL}^{-1}$ for suitable rumen fermentation. Patra et al. (2014), in a meta-analyses study about lipid effects on ruminal parameters, observed that, on average, ruminal $\mathrm{N}-\mathrm{NH}_{3}$ was $12.9 \mathrm{mg} \mathrm{dL}$. Here, the minimum was 
$3.1 \mathrm{mg} \mathrm{dL}^{-1}$, and the maximum $34.5 \mathrm{mg} \mathrm{dL}^{-1}$. These results indicated high variability between the treatments. After $\left(\mathrm{T}_{30}\right)$ fermentation, the $\mathrm{N}-\mathrm{NH}_{3}$ concentration was, on average, $23.2 \mathrm{mg} \mathrm{dL}{ }^{-1}$. The $\mathrm{N}-\mathrm{NH}_{3}$ balance was positive, on average, $1.31 \mathrm{mg} \mathrm{dL}^{-1} \mathrm{~h}^{-1}$. Positive balance is an indication that the amount of $\mathrm{N}-\mathrm{NH}_{3}$ in the rumen was sufficient for microorganism growth and microbial protein production.

Although urea concentration was higher in the Control diet, the supplemented diets had a higher NFC concentration (Table 1). The $\mathrm{N}-\mathrm{NH}_{3}$ rapidly released by the urea was in equilibrium with the quick energy available from NFC. Cottonseed treatments also had higher fiber content (Table 1); the energy available was released slowly, as it equilibrated with the $\mathrm{N}^{-\mathrm{NH}_{3}}$ released by protein from cottonseed. As a consequence, the balance of $\mathrm{N}_{-} \mathrm{NH}_{3}$ was similar among treatments. An optimum $\mathrm{N}-\mathrm{NH}_{3}$ level cannot be a fixed value because microorganisms need to utilize the $\mathrm{N}-\mathrm{NH}_{3}$, and consequently, microbial protein production is dependent on carbohydrate fermentation rates (energy availability) (Van Soest, 1994).

Dietary lipid supplementation may influence SCFA production, depending on the composition of the basal diet and the amount of lipid added (Benchaar et al., 2012; Chelikani et al., 2004; Shingfield et al., 2008). In the present study, propionate had similar production levels; however, acetate and butyrate had lower production when cottonseed was included. Propionate is used for glucose production, and it is also the major substrate of hepatic gluconeogenesis. The propionate pathway is more efficient than that of acetate. To convert an mol of glucose in acetate, $251 \mathrm{kcal} \mathrm{mol}^{-1}$ is necessary; whereas, only $60 \mathrm{kcal} \mathrm{mol}^{-1}$ is needed to convert in propionate (Kozloski, 2002). Additionally, the acetate pathway releases $\mathrm{H}_{2}$, which causes a simultaneous increase in propionate and a decrease in acetate. This balance contributes to improving the energy efficiency of the animal and decreases free $\mathrm{H}_{2}$ in the rumen.

Given the results observed in this study, it is possible to conclude that the primary effects of administering cottonseed into the diet are much more dependent on lipids than fiber, as previously illustrated by the decreases in acetic and butyric acids. If the effects of fiber in cottonseed were more prominent than those of lipid effects, we would expect an increase in acetic and butyric acid production, which was not observed here. Conversely, if the effects of cottonseed in rumen fermentation were more dependent on its lower NFC content, a decrease in propionic acid production would be expected. This decrease was not, in fact, observed, thus, it is reasonable to conclude that the carbohydrate type in cottonseed composition is less important than its lipid content.

Acetate and butyrate have cellulose and hemicellulose as major precursors. These fibrous carbohydrates have a slower digestion rate in the rumen than do the non-fiber-carbohydrates. Consequently, fibrous carbohy- drate products are released slowly. Cottonseed inclusion increased cellulose and hemicellulose content in the diet, resulting in slower acetate and butyrate production vs. the Control. Sullivan et al. (2005) reported that both the acetate molar proportion and the acetate to propionate ratio decreased linearly as dietary fatty acids (FA) from the whole cottonseed increased.

Moreover, propionate has NFC as its major precursor. This study demonstrated that, although cottonseed diets had lower NFC, they had higher lipids. In the rumen, lipids cannot ferment, rather they are hydrolyzed. The products of lipid hydrolyzation are fatty acids and glycerol, which are quickly fermented by microorganisms and then mostly converted into propionate. Propionate, therefore, had a similar production rate with different precursors.

In the present study, vitamin $\mathrm{E}$ had no effect on SCFA. This is in disagreement with in vitro studies. Naziroğlu et al. (2002) supplemented $0.4 \mathrm{mg}$ and $0.8 \mathrm{mg}$ of vitamin $\mathrm{E}$ in $100 \mathrm{~mL}$ rumen fluid and observed that this inclusion increased acetic and propionate concentrations and decreased butyrate concentration. Hou et al. (2013) reported that supplementing vitamin E at $2 \mathrm{mg}$ per $80 \mathrm{~mL}$ in incubation liquid increased in vitro rumen acetate and total SCFA production, as well as decreasing butyrate production. Wei et al. (2015) added 0, 7.5, 15, $30 \mathrm{IU}$ vitamin $\mathrm{E} \mathrm{kg}^{-1}$ of DM in an in vitro trial and observed that supplementing vitamin E not only increased the total SCFA and propionate, but also tended to increase acetate production ( $p=0.084)$. This is simply an observation. Our study was an in vivo trial and did not reflect these in vitro results.

Considering then the level of vitamin E used (as recommended by previous studies), there were no safety concerns about the real vitamin $\mathrm{E}$ intake for the cows. The vitamin $\mathrm{E}$ was mixed into the concentrate and offered to the animals; thus, the amount of vitamin E cannot have been enough to cancel out or minimize oxidative stress on ruminal microorganism. Further research is certainly necessary to confirm the levels of vitamin $\mathrm{E}$ on minimizing oxidative stress in the rumen in order to facilitate positive effects in the ruminal fermentation process. The mechanism(s) by which antioxidant compounds improve the toxic effect of excessive unsaturated fatty acids has not been well documented and may vary according to the antioxidant compound and type of fat (Vázquez-Añón and Jenkins, 2007).

Our experimental results indicate that enteric methane emissions decreased significantly (by approximately $42 \%$ ) in animals on the cottonseed diets compared to the basal diet. The reduction in intensity of $\mathrm{CH}_{4}$ emissions (as $\mathrm{g}$ of $\mathrm{CH}_{4} \mathrm{~kg}^{-1}$ of DM) with the cottonseed diet was higher in our study than in the studies of both Martin et al. (2008) and Beauchemin et al. (2009b), in which the deceases were only $27 \%$ and $18 \%$, respectively. This difference may be due to the high lipid content in our cottonseed diet compared with those of the other authors. 
Our results suggest that, for each percentage of lipids added in the cows' diet, the result was a reduction of $8 \%$ in the methane emission. This result was higher than that found by Patra et al. (2014). In a metaanalysis study, they concluded that, for each percentage of lipid added, the result was a reduction of $4 \%$ in methane emissions. Again, this difference is likely due to the higher oil level used in the present experiment. According to Beauchemin et al. (2008), there exists a linear relationship between the percentage of lipids added and the reduction in $\mathrm{CH}_{4}$ emissions.

The inhibitory effect of lipids on enteric methane emissions has been widely reported in studies, although the extent of inhibition appears to be variable (Brask et al., 2013; Grainger and Beauchemin, 2011). Several mechanisms have been recognized for their inhibitory effects of lipids on methane emissions. Lipids inhibit methanogenesis by reducing the metabolic activity and the numbers of ruminal methanogens and protozoa.

The biohydrogenation of unsaturated fatty acids is an alternative hydrogen sink, and it decreases free hydrogen in the rumen (Beauchemin et al., 2009a; Johnson and Johnson, 1995). However, according to Mills et al., 2001 , only between 1 and $3 \%$ of $\mathrm{H}_{2}$ is taken up for biohydrogenation, which consists of $\mathrm{H}$ saturation of the double bonds of unsaturated fatty acids.

Lipids are not fermented in the rumen, and, thus, they do not produce a surplus of free hydrogen. Among the SCFA, acetate production releases the highest amount of ruminal free hydrogen; therefore, by decreasing the acetate production, the free hydrogen concentration will be reduced. Consequently, methane production could decline directly, either by reducing the methanogen numbers and/or activity - or indirectly - by production and/or concentration of less hydrogen, when higher cottonseed levels are included in the diets.

The pattern of SCFA production and methane emissions during the day increased rapidly after feeding and then decreased slowly until the next feeding. SCFA and methane production peaked immediately after postfeeding (Figure 2), as had been previously demonstrated by Mao et al. (2010).

\section{Gastrointestinal energy released}

Notably, energy release in the rumen is related to SCFA and methane production and their heating powers, as well as to the ruminal solid mass amount. Cottonseed treatments had $32 \%$ higher ruminal solid mass vs. the Control. Ruminal propionate production is an expression of ruminal mass to equate to other similar treatment values. Table 2 demonstrates that the highest ruminal solid mass with cottonseed treatments induced a higher propionate release in the rumen. This was in the order of $42 \%$, when expressed as $\mathrm{MJ} \mathrm{d}^{-1}$ vs. the Control. Acetate production from the cottonseed treatments was $34 \%$ lower when expressed as ruminal mass (Table 2) vs. the Control; however, the higher ruminal solid mass for the cottonseed treatments cancels out this lower ac- etate production (and thereby the acetate released in the rumen) when it is expressed as $\mathrm{MJ} \mathrm{d}^{-1}$. This was similar among all the treatments.

In spite of higher ruminal solid mass from the cottonseed treatments, there was an expressive reduction in the butyrate production - in the order of $47 \%$ when expressed as ruminal mass (Table 2). This was enough to further an approximate decrease of $32 \%$ in energy release in the rumen, when expressed as $\mathrm{MJ} \mathrm{d}^{-1}$ vs. the Control. A similar situation was observed for the methane, in which a lower ruminal methane production, in the order of $42 \%$ when expressed as ruminal mass (Table 2), was enough to further a decrease in ruminal energy release of $26 \%$, when expressed as $\mathrm{MJ} \mathrm{d}^{-1}$ for the cottonseed treatments as compared to the Control.

Changes in the energy release site did occur. In the rumen of cows fed cottonseed, less energy was released as methane and butyrate (expressed as $\mathrm{MJ} \mathrm{d}^{-1}$ ) in the percentages of GE or DE; therefore, more energy was released in the intestine due to energy released in the feces. This was similar among all the treatments. The energy release in the intestine (expressed in $\mathrm{MJ} \mathrm{d}^{-1}$ ) was $57 \%$ higher for the cows fed cottonseed compared to cows fed the Control.

Methane production in cattle typically accounts for 5 to $6 \%$ of GEI (Johnson and Ward, 1996); however, values of 2 to $12 \%$ (Johnson and Johnson 1995) have been reported for some diets. Martin et al. (2008), using linseed as a lipid source for lactating cows, maintained a dietary level of $7 \%$ for lipids and observed that $\mathrm{CH}_{4}$ output represented $6 \%$ of GEI. In the current study, our data are in agreement with these authors; our $\mathrm{CH}_{4}$ emissions averaged $6 \%$ of GEI in the cottonseed treatments and $10 \%$ of GEI in the Control treatment. Since methane represents a loss of dietary energy, a significant reduction in gas emissions was observed for the cows fed cottonseed, and this indicated that these animals were more efficient in utilizing dietary energy than those in the Control.

\section{Conclusions}

Cottonseed inclusion in cattle diets can be considered as a methane mitigation strategy. Changes in the ruminal products, such as lower acetate, butyrate, and methane production are favorable with the use of cottonseed in cattle diets. The inclusion of vitamin

$\mathrm{E}$ in vivo studies may not improve ruminal fermentation in cows.

\section{Acknowledgments}

The authors thank the University of São Paulo employers, professors, trainees and São Paulo Research Foundation (FAPESP) for the grant number: 2013/119835. FAPESP provided funding through scholarship, experimental design, laboratory analysis and English language review. 


\section{Authors' Contributions}

Conceptualization: Nogueira, R.G.S.; Rodrigues, P.H.M.; Pereira. A.S.C. Data acquisition: Nogueira, R.G.S.N.; Perna Junior, F.; Cassiano, E.C.O.; Carvalho, R.F. Data analysis: Nogueira, R.G.S.N.; Rodrigues, P.H.M. Writing and editing: Nogueira, R.G.S.N.; Rodrigues, P.H.M.

\section{References}

Andrae, J.G.; Duckett, S.K.; Hunt, C.W.; Pritchard, G.T.; Owens, F.N. 2001. Effects of feeding high-oil corn to beef steers on carcass characteristics and meat quality. Journal of Animal Science 79: 582-588.

Andrews, J.; Vazquez-Anon, M.; Bowman, G. 2006. Fat stability and preservation of fatty acids with AGRADO (R) antioxidant in feed ingredients used in ruminant rations. Journal of Animal Science 84: 60-60.

Association of Official Analytical Chemists [AOAC]. 1995. Official Methods of Analysis. 16ed. Rockville, MD, USA.

Bateman, J. 1970. Animal Nutrition: Manual of Analytical Methods = Nutrición Animal: Manual de Métodos Analíticos. Herrero Hermanos, Mexico City, Mexico (in Spanish).

Beauchemin, K.A.; McGinn, S.M.; Petit, H.V. 2007. Methane abatement strategies for cattle: lipid supplementation of diets. Canadian Journal of Animal Science 87: 431-440.

Beauchemin, K.A.; Kreuzer, M.; O'Mara, F.; McAllister, T.A. 2008. Nutritional management for enteric methane abatement: a review. Australian Journal of Experimental Agriculture 48: 21-27.

Beauchemin, K.A.; McGinn, S.M.; Benchaar, C.; Holtshausen L. 2009a. Crushed sunflower, flax, or canola seeds in lactating dairy cow diets: effects on methane production, rumen fermentation, and milk production. Journal of Dairy Science 92: 2118-2127.

Beauchemin, K.A.; McAllister, T.A.; McGinn, S.M. 2009b. Dietary mitigation of enteric methane from cattle. CAB Reviews: Perspectives in Agriculture, Veterinary Science, Nutrition and Natural Resources 4: 1-18.

Beauchemin, K.A.; Janzen, H.H.; Little, S.M.; McAllister, T.A.; McGinn, S.M. 2011. Mitigation of greenhouse gas emissions from beef production in western Canada: evaluation using farm-based life cycle assessment. Animal Feed Science and Technology 166: 663-677.

Benchaar, C.; Romero-Pérez, G.A.; Chouinard, P.Y.; Hassanat, F.; Eugene, M.; Petit, H.V.; Côrtes, C. 2012. Supplementation of increasing amounts of linseed oil to dairy cows fed total mixed rations: effects on digestion, ruminal fermentation characteristics, protozoal populations, and milk fatty acid composition. Journal of Dairy Science 95: 4578-4590.

Brask, M.; Lund, P.; Weisbjerg, M.R.; Hellwing, A.L.F.; Poulsen, M.; Larsen, M.K.; Hvelplund, T. 2013. Methane production and digestion of different physical forms of rapeseed as fat supplements in dairy cows. Journal of Dairy Science 96: 23562365.

Brioukhanov, A.L.; Netrusov, A.I. 2004. Catalase and superoxide dismutase: distribution, properties, and physiological role in cells of strict anaerobes. Biochemistry 69: 949-962.
Buddle, B.M.; Denis, M.; Attwood, G.T.; Altermann, E.; Janssen, P.H.; Ronimus, R.S.; Pinares-Patino, C.S.; Muetzel, S.; Wedlock, D.N. 2011. Strategies to reduce methane emissions from farmed ruminants grazing on pasture. The Veterinary Journal 188: 11-17.

Bloomberg, B.D.; Hilton, G.G.; Hanger, K.G.; Richards, C.J.; Morgan, J.B.; Van Overbeke, D.L. 2011. Effects of vitamin E on color stability and palatability of strip loin steaks from cattle fed distillers grains. Journal of Animal Science 89: 3769-3782.

Chelikani, P.K.; Bell, J.A.; Kennelly, J.J. 2004. Effects of feeding or abomasal infusion of canola oil in Holstein cows. 1. Nutrient digestion and milk composition. Journal of Dairy Research 71: 279-287.

Chilibroste, P.; Tamminga, S.; Boer, H.; Gibb, M.J.; Den Dikken, G. 2000. Duration of regrowth of ryegrass (Lolium perenne) effects on grazing behavior, intake, rumen fill, and fermentation of lactating dairy cows. Journal of Dairy Science 83: 984-995.

Conceição, D.; Jacques, R.; Bento, F.; Simonetti, A.; Selbach, P.; Camargo, F. 2007. Reduction of hexavalent chromium by isolated bacteria of contaminated soils with chromium = Redução de cromo hexavalente por bactérias isoladas de solos contaminados com cromo. Ciência Rural 37: 1661-1667 (in Portuguese).

Dini, Y.; Gere, J.; Briano, C.; Manetti, M.; Juliarena, P.; Picasso, V.; Gratton, R.; Astigarraga, L. 2012. Methane emission and milk production of dairy cows grazing pastures rich in legumes or rich in grasses in Uruguay. Animals 2: 288-300.

Erwin, E.S.; Marco, G.J.; Emery, E.M. 1961. Volatile fatty acid analyses of blood and rumen fluid by gas chromatography. Journal of Dairy Science 44: 1768-1771.

Gerber, P.J.; Steinfeld, H.; Henderson, B.; Mottet, A.; Opio, C.; Dijkman, J.; Falcucci, A.; Tempio, G. 2013. Tackling Climate Change through Livestock: A Global Assessment of Emissions and Mitigation Opportunities. FAO, Rome, Italy.

Grainger, C.; Beauchemin, K.A. 2011. Can enteric methane emissions from ruminants be lowered without lowering their production? Animal Feed Science and Technology 166: 308320.

Hino, T.; Andoh, N.; Ohgi, H. 1993. Effects of $\beta$-carotene and $\alpha$-tocopherol on rumen bacteria in the utilization of long-chain fatty acids and cellulose. Journal of Dairy Science 76: 600-605.

Hou, J.; Wang, F.; Wang, Y.; Liu, F. 2013. Effects of vitamin E on the concentration of conjugated linoleic acids and accumulation of intermediates of ruminal biohydrogenation in vitro. Small Ruminant Research 111: 63-70.

Johnson, K.A.; Johnson, D.E. 1995. Methane emissions from cattle. Journal of Animal Science 73: 2483-2492.

Johnson, D.E.; Ward, G.M. 1996. Estimates of animal methane emissions. Environmental monitoring and assessment 42: 133141.

Kamiński, M.; Kartanowicz, R.; Jastrzębski, D.; Kamiński, M.M. 2003. Determination of carbon monoxide, methane and carbon dioxide in refinery hydrogen gases and air by gas chromatography. Journal of Chromatography 989: 277-283.

Kulasek, G. 1972. A micromethod for determining urea in blood plasma, whole blood and blood corpuscles with the use of urease and phenol reagent. Polskie Archiwum Weterynaryjne 15: 801-810. 
Leng, R.A. 1990. Factors affecting the utilization of 'poorquality' forages by ruminants particularly under tropical conditions. Nutrition Research Reviews 3: 277-303.

Mao, H.L.; Wang, J.K.; Zhou, Y.Y.; Liu, J.X. 2010. Effects of addition of tea saponins and soybean oil on methane production, fermentation and microbial population in the rumen of growing lambs. Livestock Science 129: 56-62.

Martin, C.; Rouel, J.; Jouany, J.P.; Doreau, M.; Chilliard, Y. 2008. Methane output and diet digestibility in response to feeding dairy cows crude linseed, extruded linseed, or linseed oil1. Journal of Animal Science 86: 2642-2650.

Martin, C.; Morgavi, D.P.; Doreau, M. 2010. Methane mitigation in ruminants: from microbe to the farm scale. Animal 4: 351365.

Mills, J.A.; Dijkstra, J.; Bannink, A.; Cammell, S.B.; Kebreab, E.; France, J. 2001. A mechanistic model of whole-tract digestion and methanogenesis in the lactating dairy cow: model development, evaluation, and application. Journal of Animal Science 79: 1584-1597

Naziroğlu, M.; Güler, T.; Yüce, A. 2002. Effect of vitamin E on ruminal fermentation in vitro. Transboundary and Emerging Diseases 49: 251-255.

Patra, A.K. 2014. A meta-analysis of the effect of dietary fat on enteric methane production, digestibility and rumen fermentation in sheep, and a comparison of these responses between cattle and sheep. Livestock Science 162: 97-103.
Perna Junior, F.; Cassiano, E.C.O.; Martins, M.F.; Romero, L.A.; Zapata, D.C.V.; Pinedo, L.A.; Rodrigues, P.H.M. 2017. Effect of tannins-rich extract from Acacia mearnsii or monensin as feed additives on ruminal fermentation efficiency in cattle. Livestock Science 203: 21-29.

Shingfield, K.J.; Ahvenjärvi, S.; Toivonen, V.; Vanhatalo, A.; Huhtanen, P.; Griinari, J.M. 2008. Effect of incremental levels of sunflower-seed oil in the diet on ruminal lipid metabolism in lactating cows. British Journal of Nutrition 99: 971-983.

Sullivan, H.M.; Bernard, J.K.; Amos, H.E. 2005. Ruminal fermentation and amino acid flow in Holstein steers fed whole cottonseed with elevated concentrations of free fatty acids in the oil. Journal of Dairy Science 88: 690-697.

Vázquez-Añón, M.; Jenkins, T. 2007. Effects of feeding oxidized fat with or without dietary antioxidants on nutrient digestibility, microbial nitrogen, and fatty acid metabolism. Journal of Dairy Science 90: 4361-4367.

Wei, C.; Lin, S X.; Wu, J.L.; Zhao, G.Y.; Zhang, T.T.; Zheng, W.S. 2015. Effects of supplementing vitamin $\mathrm{E}$ on in vitro rumen gas production, volatile fatty acid production, dry matter disappearance rate, and utilizable crude protein. Czech Journal of Animal Science 60: 335-341. 